\title{
KINERJA PUSKESMAS RAWALELE DALAM PELAYANAN GIZI BALITA DI KABUPATEN SUBANG
}

\author{
Oleh : \\ Luki Natika \\ Fakultas Ilmu Administrasi Universitas Subang \\ luckynatika@gmail.com
}

\begin{abstract}
ABSTRAK
Tujuan penulis melakukan penelitian ini adalah untuk mengetahui kinerja Puskesmas Rawalele dalam pelayanan gizi balita di Kabupaten Subang. Penelitian dan penulisan ini membahas hal yang berkaitan dengan kinerja Puskesmas Rawalele dalam pelayanan gizi balita di Kabupaten Subang dalam hubungannya dengan teori yaitu, Produktivitas, Kualitas Layanan, Responsivitas, Responsibilitas, dan Akuntabilitas.

Dalam pendekaan ini menggunakan metode kualitatif melalui observasi, wawancara, studi kepustakaan, dan dokumentasi. Sumber data diperoleh melalui informasi, pengamatan, dan wawancara secara langsung. Kemudian dokumen diperoleh dalam bentuk peraturanperaturan dan pengolahan data. Hasil penelitian menunjukkan bahwa kinerja Puskesmas Rawalele dalam pelayanan gizi balita di Kabupaten Subang belum optimal.

Kata Kunci : Kinerja Organisasi
\end{abstract}

\section{ABSTRACT}

The purpose of this study is the authors conducted to determine the performance of Rawalele's health center in toddler nutrition services at the Subang Regency. This research and essay are discuss about something that relating with the performance of Rawalele's health center in toddler nutrition services at the Subang Regency in conjunction with the theory is Productivity, Service Quality, Responsiveness, Responsibility, and Accountability.

In this approach using qualitative method through observation, literature study, and documentation. Sources of data obtained through information, observation, and interview directly. Then the documents were obtained in the form of rules and data processing. The results showed that the performance of Rawalele's health center in toddler nutrition services at the Subang Regency is not optimal.

Key Word: Organization Performance

\section{PENDAHULUAN}

Dalam rangka konsep penyusunan strategi peningkatan kinerja dan pelayanan, maka langkah yang akan dilakukan adalah mengembangkan faktor-faktor yang mempengaruhi kinerja tersebut, terutama mengantisipasi perkembanganan lingkungan internal dan eksternal sebagai konsekwensi dari perkembangan era globalisasi dan penerapan liberalisasi ekonomi. Untuk, itu pemerintah tetap mengoptimalkan pelayanan kepada masyarakat secara terus menerus. Pelayanan publik merupakan tanggung jawab pemerintah dan dilaksanakan oleh instansi pemerintah, baik itu dipusat, di Daerah, dan dilingkungan Badan Usaha Milik Negara. Pelayanan publik berbentuk pelayanan barang publik maupun pelayanan jasa. Dewasa ini Masyarakat semakin terbuka dalam memberikan kritik bagi pelayanan publik. Oleh sebab itu substansi administrasi sangat berperan dalam mengatur dan mengarahkan seluruh 
kegiatan organisasi pelayanan dalam mencapai tujuan.

Salah satu bentuk pelayanan publik yang dilaksanakan oleh pemerintah adalah pemenuhan kebutuhan kesehatan masyarakat. Reformasi dibidang kesehatan dilaksanakan untuk meningkatkan pelayanan kesehatan dan menjadikannya lebih efisien, efektif serta dapat dijangkau oleh seluruh lapisan masyarakat. Seperti yang tertuang dalam Keputusan Menteri Kesehatan Republik Indonesia No. 951/Menkes/SK/VI/2000 yaitu bahwa "tujuan pembangunan kesehatan adalah untuk meningkatkan kesadaran, kemauan dan kemampuan hidup sehat bagi setiap orang agar terwujud derajat kesehatan masyarakat yang optimal". Dengan meningkatnya tingkat pendidikan dan keadaan sosial dalam masyarakat maka, meningkat pula kesadaran akan arti hidup sehat dan keadaan tersebut menyebabkan tuntutan masyarakat akan pelayanan kesehatan yang bermutu, nyaman dan berorientasi pada kepuasan konsumen semakin mendesak dimana diperlukan pelayanan yang tinggi.

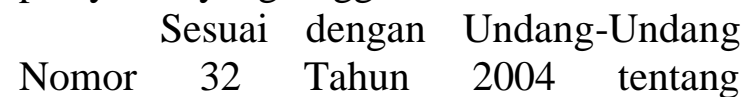
Pemerintahan Daerah ditetapkan bahwa bidang pemerintahan yang wajib dilaksanakan oleh Daerah Kabupaten dan Daerah Kota adalah pekerjaan umum, kesehatan, pendidikan, dan kebudayaan, pertanian, perhubungan, industry dan perdagangan, penanaman modal, lingkungan hidup, pertanahan, koperasi, dan tenaga kerja. Berdasarkan undangundang tersebut, bidang kesehatan menempati urutan kedua (setelah bidang pekerjaan umum) dari bidang pemerintahan yang wajib dilaksanakan oleh pemerintah daerah kabupaten dan kota. Adapun proses pelayanan kesehatan dan yang berkaitan dengan ketersediaan sarana kesehatan yang terdiri dari pelayanan kesehatan dasar (Puskesmas, Balai Pengobatan), pelayanan rujukan (rumah sakit), ketersediaan tenaga kesehatan, peralatan dan obat-obatan. Kinerja organisasi dalam pelayanan menyangkut hasil pekerjaan, kecepatan kerja, pekerjaan yang dilakukan sesuai dengan harapan pelanggan, dan ketepatan waktu dalam menyelesaikan pekerjaan. Pemerintah telah berusaha memenuhi kebutuhan masyarakat akan pelayanan kesehatan dengan mendirikan Pusat Kesehatan Masyarakat (PUSKESMAS). Puskesmas berfungsi sebagai :

1. Pusat penggerak pembangunan berwawasan kesehatan.

2. Pusat pemberdayaan keluarga dan masyarakat.

3. Pusat pelayanan kesehatan starata pertama.

Namun, sampai saat ini usaha pemerintah dalam memenuhi kebutuhan masyarakat akan kesehatan masih belum dapat memenuhi harapan masyarakat. Banyak anggota masyarakat yang mengeluh dan merasa tidak puas dengan pelayanan yang diberikan oleh Puskesmas milik pemerintah ini baik itu dari segi pemeriksaan yang kurang diperhatikan oleh petugas kesehatan, lama waktu pelayanan, keterampilan petugas, sarana/fasilitas, serta waktu tunggu untuk mendapatkan pelayanan. Pusat Kesehatan Masyarakat (PUSKESMAS) sebagai salah satu sarana kesehatan yang memberikan pelayanan kesehatan kepada masyarakat memiliki peran yang sangat strategis dalam mempercepat peningkatan derajat kesehatan masyarakat. Oleh karena itu Puskesmas dituntut untuk memberikan pelayanan yang bermutu yang memuaskan bagi pasiennya sesuai dengan standar yang ditetapkan dan dapat menjangkau seluruh lapisan masyarakatnya.

Puskesmas Rawalele adalah salah satu Puskesmas pemerintah di Kabupaten Subang. Penyelenggaraannya mengarahkan pada kepuasaan pasien, maka manajemen Puskesmas Rawalele mempunyai visi: "Terwujudnya Puskesmas Rawalele yang CERIA (Cermat, Efektif, Responsif, Inovatif dan Andalan) untuk mewujudkan Kabupaten dan Indonesia Sehat". Dan untuk mencapai derajat kesehatan yang optimal yang memuaskan bagi pasien 
melalui upaya kesehatan perlu adanya pelayanan yang baik yang diberikan oleh pegawai oleh sebab itu dituntut kinerja yang tinggi dari pegawai. Kinerja Puskesmas Rawalele terutama dalam pelayanan pada bidang gizi masih belum sesuai dengan keinginan masyarakat dalam hal pemeriksaan yang masih kurang diperhatikan oleh petugas, juga kinerja pegawai dalam memberikan pelayanan terhadap pasien belum maksimal dalam hal ini adalah ketetapan waktu karena masih sering terdengar keluhan pasien dan keluarganya dimana masih seringnya pegawai Puskesmas Rawalele yang lambat dalam memberikan pelayanan, dalam Undang-Undang No 36 Tahun 2009 (Pasal 143) bahwa pemerintah bertanggung jawab meningkatkan pengetahuan dan kesadaran masyarakat akan pentingnya gizi dan pengaruhnya terhadap status gizi. Informasi tentang Kinerja organisasi dapat digunakan untuk mengevaluasi apakah proses kerja yang dilakukan organisasi selama ini sudah sejalan dengan tujuan yang diharapkan atau belum. Akan tetapi dalam kenyataannya banyak organisasi yang justru kurang atau bahkan tidak jarang ada yang tidak mempunyai informasi tentang kinerja dalam organisasinya. Berdasarkan hasil penelitian, kinerja Puskesmas Rawalele dalam pelayanan gizi balita di Kabupaten Subang kurang optimal, dapat dideteksi dengan beberapa masalah sebagai berikut : kinerja Puskesmas Rawalele pada bidang gizi balita di Kabupaten Subang dimana tahun 2015 masih ada balita yang belum mendapatkan vitamin A dari target sekitar 3340 namun hanya 3012 balita yang terealisasi mendapatkan vitamin $\mathrm{A}$; dan tingkat Responsivitas masih rendah. Dari 24 balita kurang gizi di tahun 2014, ternyata masih ada 18 balita gizi kurang di tahun 2015.

\section{METODE}

Dalam penilitan ini, metode yang digunakan dalam penelitian ini menggunakan pendekatan kualiatif. Karena metode penelitian ini mampu mengeksplorasi dan memahami makna yang oleh sejumlah individu atau kelompok orang dianggap berasal dari masalah sosial kemanusiaan. Proses penelitian kualitatif ini didasarkan pada asumsi mengenai obyek empiris. Penelitian ini pun melibatkan upaya-upaya penting, seperti proses pengajuan pertanyaan-pertanyaan dan prosedur-prosedur mengumpulkan data spesifik dari para partisipan, menganalisa data secara induktif melalui tema-tema khusus ke tema-tema yang umum, dan menafsirkan makna dari data. (Creswell, 2010:4). Tujuan utama penelitian kualitatif adalah untuk memahami (to understand) fenomena atau gejala sosial dengan lebih menitik beratkan pada gambaran yang lengkap tentang fenomena yang dikaji dari pada merincinya menjadi variabel-variabel yang saling terkait. Harapannya ialah diperoleh pemahaman yang mendalam tentang fenomena untuk selanjutnya dihasilkan sebuaah teori. Karena tujuannya berbeda dengan penelitian kuantitatif, maka prosedur perolehan data dan jenis penelitian kualitatif juga berbeda.

Dalam penelitian ini penulis memilih sample penelitian kualitatif dengan menggunakan teknik non probability sampling, yaitu suatu teknik pengambilan sample yang tidak didasarkan pada perumusan statistik. Dengan demikian dalam hal ini penulis memilih untuk menggunakan teknik purposive sampling. Purposive sampling, yaitu jenis sample yang pemilihannya didasarkan atas kriteria tujuan dan manfaatnya. Informan dalam penelitian ini adalah orang-orang yang dipandang dapat memberikan informasi yang memadai (key person) tentang Kinerja Puskesmas Rawalele Dalam Pelayanan Gizi Balita Di Kabupaten Subang dengan pemilihan secara purposive sampling. Pemilihan didasarkan atas pertimbangan bahwa informan memiliki pemahaman terhadap fenomena penelitian. Kekuatan purposive sampling terletak pada pemilihan kasus-kasus yang kaya informasi (information-rich case) untuk study mendalam. Kasus-kasus yang kaya 
informasi diperoleh dari orang-orang tertentu yang memungkinkan peneliti mempelajari berbagai issue sentral yang penting bagi tujuan penelitian.

\section{HASIL DAN PEMBAHASAN} Kinerja Puskemas Rawalele Dalam Pelayanan Gizi Balita Di Kabupaten Subang

Pada saat melaksanakan penelitian di puskesmas rawalele. Penulis juga melakukan berbagai macam bidang kegiatan yang berhubungan langsung kepada masyarakat, seperti mewawancarai masyarakat yang mempunyai balita dan juga mewawancarai petugas gizi balita dipuskesmas rawalele. Dalam melaksanakan wawancara, penulis menemukan keluhan-keluhan dari masyarakat atau ibu balita akan pelayanan gizi balita.

Kinerja merupakan suatu hasil melaksanakan suatu tugas atau pekerjaannya sesuai dengan tanggung jawab yang di berikan kepadanya dalam upaya untuk mencapai suatu tujuan dalam organisasinya, dari uraian diatas dapat diperoleh suatu gambaran bahwa kinerja seorang pegawai merupakan suatu penilaian terhadap pelayanan yang berkaitan dengan pelaksanaan kegiatan, kemampuan dalam pembuatan perencanaan, dan kemampuan berkomunikasi seseorang baik dengan atasan ataupun bawahannya. Dilihat secara psikologi, kemampuan pegawai terdiri dari kemampuan dalam hal kepintaran dan juga kemampuan dalam hal keahlian. Artinya pegawai yang memiliki kemampuan diatas rata-rata dengan pendidikan sehari-hari, maka ia akan lebih mudah mencapai kinerja yang diharapkan. Oleh sebab itu, pegawai perlu ditempatkan pada pekerjaan yang sesuai dengan keahliannya.

Penilaian suatu kinerja dalam organisasi dapat dijadikan sebagai tolak ukuran keberhasilan suatu organisasi dalam mencapai misi yang ditetapkan. Sehingga penilaian kinerja bisa dianggap penting.
Suatu pelayanan yang optimal adalah jika didalamnya terdapat dimensi-dimensi yang digunakan untuk tolak ukur keberhasilan. Dalam bab ini penulis akan membahas tentang hasil dan pembahasan dalam penelitian tentang kinerja puskesmas rawalele dalam pelayanan gizi balita dikabupaten subang untuk mengukur kinerja organisasi digunakan dimensidimensi Produktivitas, Kualitas Layanan, Responsivitas, Responsibilitas, dan Akuntabilitas. Selain itu akan dibahas kendala yang dihadapi oleh penulis dalam pelaksanaan wawancara.

\section{Produktivitas}

Dwiyanto (2006: 50-51)

Mengemukakan bahwa konsep produktivitas tidak hanya mengukur tingkat efisiensi, tetapi juga efektivitas pelayanan. Produktivitas umumnya dipahami secara umum sebagai rasio antara input dengan output. Produktivitas juga merupakan bentuk kemampuan organisasi untuk mengenali kebutuhan masyarakat dalam pelayanan publik. Dalam kinerja suatu organisasi, produktivitas merupakan suatu bahan pertimbangan bagi organisasi dalam mengenali serta menelaah kebutuhan yang dibutuhkan masyarakat, produktivitas merupakan aspek penting yang harus diperhatikan dalam kinerja oeganisasi agar kebutuhan yang sebenarnya dibutuhkan oleh masyarakat dapat terpenuhi secara maksimal. Produktivitas mengedepankan bagaimana suatu organisasi dalam melayani masyarakat secara efektif. Dalam wawancara yang penulis lakukan dengan kepala Puskesmas Rawalele, sebagai berikut: "Pekerjaan yang petugas lakukan belum berjalan dengan efektif dan efisien dalam memberikan penyuluhan pelayanan untuk tumbuh kembangnya anak balita dikarenakan masih ada balita yang belum tersentuh pelayanan, misalnya pada saat sosialisasi tidak datang". Tanggapan yang sama juga dalam wawancara yang penulis lakukan dengan petugas gizi balita, sebagai berikut: "Memang benar masih banyak masalah ketika petugas melakukan 
sosialisasi penyuluhan. Contohnya kadang suka ada ibu yang punya balita tapi tidak datang pada waktu sosialisasi penyuluhan, jadi sibalita tidak sempat diberikan vitamin A".

Jika dilihat dari pendapat diatas, penulis dapat menyimpulkan bahwa pelayanan yang diberikan petugas ini dalam menjalankan tugasnya memang belum sepenuhnya maksimal sesuai yang diharapkan dalam memberikan pelayanan, hal ini dikarenakan belum semua balita tersentuh sosialisasi penyuluhan dan mendapatkan vitamin A dari petugas. Sedangkan dalam wawancara yang penulis lakukan dengan masyarakat yang mempunyai balita, sebagai berikut: "Kurang tahu juga soalnya anak saya suka dititpin ke neneknya karena sehari-hari saya kerja dipabrik". Merujuk pada wawancara diatas, penulis mencoba menindaklanjuti hasil tersebut kepada nenek sibalita: "Tidak tahu juga, nenek kurang mengerti soal program pemerintah. Terus ga tahu juga kalau ada pengemuman penimbangan balita ke posyandu teh".

\footnotetext{
Berdasarkan hasil wawancara dengan masyarakat dapat penulis simpulkan bahwa kinerja Puskesmas Rawalele dalam pelayanan gizi balita dalam hal sosialisasi penyuluhan dan pemberian vitamin A kepada balita belum optimal. Karena sosialisasi yang dilakukan belum sampai kepada semua keluarga yang memiliki balita. Adapun pendapat lain dalam wawancara yang penulis lakukan dengan kepala Puskesmas Rawalele, sebagai berikut : "Kinerja Puskesmas Rawalele belum sepenuhnya tercapai dalam pelayanan gizi balita kepada masyarakat ini karena proses pelayanan yang ada belum berjalan dengan baik". Sedangkan dalam wawancara yang penulis lakukan dengan petugas gizi balita, sebagai berikut: "Tahapan selama kegiatan pelayanan gizi kepada balita terkadang terhambat banyak masalah sehingga apa yang menjadi tujuan dari program ini pun terkadang belum semuanya tercapai".
}

Berdasarkan hasil wawancara diatas penulis dapat menyimpulkan bahwa tujuan dari pelayanan gizi balita di Puskesmas Rawalele belum dapat tercapai sepenuhnya sehingga kinerja yang dihasilkanpun belum bisa optimal. Adapun dalam wawancara yang penulis lakukan dengan masyarakat yang mempunyai balita, sebagai berikut: "Tujuannya belum tercapai, karena seperti di desa saya saja masih ada masyarakat yang mempunyai anak balita tapi belum mendapatkan seperti vitamin A dan PMT(pemberian makanan tambahan)". Berdasarkan hasil wawancara diatas tersebut dengan masyarakat dapat penulis simpulkan bahwa kinerja Puskesmas Rawalele belum optimal. Hal ini disebabkan belum sepenuhnya tujuan dari program pelayanan gizi balita ini dapat tercapai. Diupayakan agar kinerja Puskesmas Rawalele lebih dapat ditingkatkan lagi terkhusus terhadap beberapa hal yang menjadi tujuan utama program gizi balita ini.

\section{Kualitas Layanan}

Dwiyanto

(2006;50-510)

mengemukakan bahwa kualitas layanan merupakan isu mengenai kualitas layanan yang cenderung menjadi penting dalam menjelaskan organisasi publik. Hal ini disebabkan adanya pandangan negatif yang terbentuk mengenai organisasi publik muncul karena ketidakpuasan masyarakat terhadap kualitas layanan yang diterima. Dengan demikian kualitas layanan dapat dijadikan indikator kinerja organisasi publik. Seperti yang telah dijelaskan bahwa kinerja organisasi publik juga dapat dilihat dari kualitas pelayanan yang diberikan organisasi publik tersebut kepada masyarakat. Kualitas pelayanan Puskesmas Rawalele adalah bagaimana dalam memberikan pelayanan kepada masyarakat dan menyangkut pertanggung jawaban pelayanannya. Kualitas layanan merupakan suatu hal yang sangat penting dalam kinerja organisasi karena menyangkut bagaimana organisasi tersebut memberikan pelayanan kepada masyarakat. Demikian pula dengan 
Puskesmas Rawalele dalam memberikan pelayanan, kualitas layanan yang diberikan merupakan tolak ukur atas baik atau buruknya sebuah pelayanan yang diberikan gizi balita terhadap pasien. Dalam memberikan pelayanan, kualitas layanan harus diupayakan sebaik mungkin agar pelayanan yang diberikan kepada balita dapat dilaksanakan secara maksimal dan kebutuhan gizi balita dapat terpenuhi.

Salah satu bentuk kualitas layanan adalah mengenai informasi dan komunikasi yang menyangkut pada pelayanan masyarakat, karena sebagai penyedia pelayanan harus selalu memperhatikan kebutuhan masyarakat. Berdasarkan dalam wawancara yang penulis lakukan dengan kepala Puskesmas Rawalele, sebagai berikut: "Komunikasi yang petugas jalin dengan orang tua balita setiap bulan satu kali kegiatan pelayanan gizi diposyandu dan memberikan penyuluhan ke 10 desa yang berada diwilayah kerja Puskesmas Rawalele, sehingga petugas tidak terkaper dan kesulitan untuk memberikan informasi terhadap orang tua balita".

Adapun dalam wawancara yang penulis lakukan dengan petugas gizi balita, sebagai berikut: "Sebenarnya petugas sudah menjalin komunikasi dan memberikan informasi dengan baik kepada orang tua balita, akan tetapi sebagian masyarakat atau orang tua balita yang acuh akan pentingnya gizi sehingga petugas dan orang tua balita tidak bisa menjalin komunikasi dengan baik". Berdasarkan kutipan wawancara yang disampaikan oleh Kepala Puskesmas dan petugas gizi balita Puskesmas Rawalele, dapat penulis simpulkan ada beberapa permasalahan yang menyebabkan kualitas layanan belum optimal diantaranya jumlah petugas gizi balita yang belum bisa mengkaper proses pelayanan di 10 desa dan perilaku dari sebagian masyarakat atau orang tua balita itu sendiri yang acuh.

Sedangkan dalam wawancara yang penulis lakukan dengan masyarakat yang mempunyai balita, sebagai berikut: "Kalau sosialisasi kepada masyarakat yang mempunyai balita telah berjalan dengan baik akan tetapi dalam proses pemberian informasi tentang materi sering kali banyak yang tidak mengerti oleh kalangan masyarakat".

Dari pernyataan diatas maka penulis dapat menyimpulkan bahwa dalam menjalankan pelayanan gizi balita memang belum sepenuhnya mencapai target maksimal yang diharapkan hal tersebut dikarenakan adakalanya kurang kesadaran dari warga masyarakat khususnya ibu balita akan pentingnya gizi anak balitanya dikarenakan oleh berbagai hal yang menjadi asumsi-asumsi masing-masing. Akan tetapi hal tersebut tidak mengurangi kualitas layanan sosialisasi pihak pemerintah kepada masyarakat. Dalam kenyataannya petugas telah bergerak untuk mensosialisasikan setiap agenda program pelayanan gizi balita kesetiap daerah wilayah kerja Puskesmas Rawalele, walaupun dengan jumlah petugas gizi yang minim.

Sedangkan untuk jawaban lain dalam wawancara yang penulis lakukan dengan kepala Puskesmas Rawalele, sebagai berikut: "Untuk saat ini pelayanan yang kami berikan belum bisa dikatakan cepat atau lambat namun kami berupaya agar petugas kami bisa memberikan pelayanan yang prima terhadap balita". Adapun dalam wawancara yang penulis lakukan dengan petugas gizi balita, sebagai berikut: "Setiap ditemukan balita yang bermasalah gizi kurang di 10 desa wilayah kerja Puskesmas Rawalele kami belum bisa menangani dengan cepat dan tepat dalam memberikan pelayanan hal ini dikarenakan tidak terkapernya akibat jumlah petugas yang terbatas". Berdasarkan kutipan wawancara diatas penulis dapat menyimpulkan telah jelas bahwa kinerja Puskesmas Rawalele dalam pelayanan gizi balita belum cepat dan tepat, dikarenakan jumlah tenaga petugas yang belum bisa mengkaper pelayanan di 10 desa. Sedangkan dalam wawancara yang penulis lakukan dengan masyarakat yang mempunyai balita, sebagai berikut: 
"Biasanya kalau penyuluhan diposyandu petugas belum bisa dengan cepat dan tepat. Kadang nunggu giliran pemeriksaan juga lama”. Berdasarkan pernyataan diatas penulis dapat disimpulkan bahwa masyarakat menginginkan pelayanan yang cepat dan tepat bahwa program pelayanan gizi balita ini yang telah dibentuk agar kualitas pelayanan yang diberikan kepada balita tersebut dapat ditingkatkan lagi, karena kualitas kerja yang baik akan mampu menciptakan dan membuat suatu pelayanan yang berkualitas.

Puskesmas Rawalele Kabupaten Subang mempunyai tanggung jawab yang besar dalam program pelayanan gizi balita, untuk itu jumlah petugas dan tingkat pendidikan yang tinggi sangat mempengaruhi dalam menciptakan kesehatan balita, karena petugas adalah pelaksana kegiatan dalam memberikan pelayanan terhadap gizi balita.

\section{Responsivitas}

Dwiyanto

(2006:50-51)

mengemukakan bahwa responsivitas adalah kemampuan organisasi untuk mengenali kebutuhan masyarakat, dan mengembangkan program-program pelayanan dan mengembangkan programprogram pelayanan publik sesuai dengan kebutuhan dan aspirasi masyarakat. Responsivitas dimasukan sebagai salah satu indikator kinerja karena responsivitas secara langsung menggambarkan kemampuan organisasi publik dalam menjalankan misi dan tujuannya, terutama untuk memenuhi kebutuhan masyarakat. Puskesmas Rawalele Kabupaten Subang adalah salah satu organisasi pelayanan publik yang selalu berusaha memberikan pelayanan terbaik berupa pelayanan prima agar dapat memenuhi kebutuhan dan harapan masyarakatnya untuk itu dituntut Puskesmas Rawalele harus selalu tanggap terhadap kebutuhan masyarakat serta keluhan-keluhan yang disampaikan oleh masyarakat. Konsep responsivitas mengarah pada pertanggung jawaban organisasi publik dalam memberikan pelayanan kepada masyarakat. Untuk itu Puskesmas Rawalele dituntut semaksimal mungkin agar bisa mengembangkan program-program yang sudah berjalan yang bertujuan untuk mensejahterakan dan memberikan kesehatan kepada masyarakat. Puskesmas Rawalele harus serta merta terus berupaya memberikan pelayanan kesehatan kepada balita sebaik mungkin agar terciptanya kesehatan dan senantiasa tercapai sesuai dengan yang telah ditetapkan sebelumnya dan tujuan program pelayanan gizi balita dapat terealisasi dengan baik.

Dalam wawancara yang penulis lakukan dengan kepala Puskesmas Rawalele, sebagai berikut: "Dalam pelayanan gizi balita ini memang kinerja Puskesmas belum bisa sepenuhnya untuk memenuhi kebutuhan balita dan belum bisa memberikan pelayanan yang maksimal". Sedangkan dalam wawancara yang penulis lakukan dengan petugas gizi balita, sebagai berikut: "Petugas sudah berupaya untuk melayani balita namun dengan stock terbatas dan segitu banyaknya balita di 10 desa wilayah kerja Puskesmas Rawalele dalam pemberian vitamin A, (PMT) pemberian makanan tambahan kami belum bisa sepenuhnya memenuhi kebutuhan balita tersebut dalam memberikan pelayanan yang maksimal". Berdasarkan hasil wawancara diatas penulis menyimpulkan bahwa pemenuhan kebutuhan terhadap balita belum sepenuhnya maksimal. Hal ini dikarenakan adanya keterbatasan petugas gizi balita dan stock vitamin A serta PMT (Pemberian Makanan Tambahan) yang terbatas. Sedangkan dalam wawancara yang penulis lakukan dengan masyarakat yang mempunyai balita, sebagai berikut: "Biasanya kebutuhan balita suka tidak terpenuhi semua. Contohnya saya sesudah melakukan penimbangan anak saya pernah tidak kebagian (PMT) Pemberian makanan tambahan".

Berdasarkan hasil wawancara diatas penulis menyimpulkan bahwa dalam pelayanan gizi balita ini masih mengalami 
beberapa masalah yang menghambat tercapainya pemenuhan kebutuhan gizi balita ini. Sehingga petugas gizi balita di Puskesmas Rawalele masih perlu untuk berupaya untuk mengatasi beberapa masalah yang ada agar kinerja dalam pelayanan gizi balita dapat berjalan jauh lebih baik lagi sehingga kebutuhan balita dapat terpenuhi dengan baik, efektif, dan efisien. Sedangkan untuk jawaban dalam wawancara yang penulis lakukan dengan kepala Puskesmas Rawalele, sebagai berikut: "Memang benar aspirasi tentang pelayanan gizi balita dari masyarakat khususnya yang mempunyai balita itu sudah banyak yang masuk, akan tetapi petugas kami belum bisa merealisasikan sepenuhnya aspirasi dari masyarakat yang mempunyai balita tersebut". Adapun dalam wawancara yang penulis lakukan dengan petugas gizi balita, sebagai berikut: "Sebagian masyarakat yang mempunyai balita memang sudah menyampaikan aspirasinya mengenai pelayanan yang kami berikan dan untuk sampai saat ini kami berupaya dan berupaya agar aspirasi keluhan dari ibu balita bisa kami benahi atau diperbaiki untuk memberikan pelayanan yang prima tidak semuanya langsung bisa diproses dengan cepat, namun perlu bertahap". Berdasarkan hasil wawancara diatas penulis menyimpulkan bahwa dalam pelaksanaannya aspirasi dari masyarakat selalu ada, namun dalam prosesnya belum semua aspirasi dapat direalisasikan dengan baik karena perlu adanya pembenahan dan perbaikan yang dilakukan secara bertahap. Sedangkan dalam wawancara yang penulis lakukan dengan masyarakat yang mempunyai balita, sebagai berikut: "Aspirasi kami belum bisa sepenuhnya terealisasikan oleh Puskesmas Rawalele, akan tetapi kami selalu berharap agar keluhan kami tentang pelayanan gizi balita ini bisa menjadi masukan agar selanjutnya petugas bisa memberikan pelayanan yang baik terhadap anak kami".

Berdasarkan hasil wawancara diatas penulis berkesimpulan bahwa petugas masih kurang atau belum tanggap terhadap masukan atau aspirasi dari masyarakat yang mempunyai balita. Hal ini menunjukan bahwa Puskesmas Rawalele sebagai pemberi layanan terkait bidang nutrisionis dalam pelayanan gizi balita masih kurang siap untuk melayani balita sehingga petugas masih perlu untuk melakukan perbaikan atau evaluasi dalam kinerja pelayanan gizi balita kedepannya, kinerja yang dihasilkan tidak terbuang siasia dan menimbulkan dampak positif untuk program kerja selanjutnya yang mana hal tersebut sangat membantu dalam proses tumbuh kembang anak balita.

\section{Responsibilitas}

Dwiyanto

(2006:50-51)

menyatakan responsibilitas menjelaskan apakah pelaksanaan kegiatan organisasi publik itu dilakukan sesuai dengan prinsipprinsip administrasi yang benar atau sesuai dengan kebijakaan organisasi, baik yang eksplisit maupun implisit. Oleh sebab itu, responsibilitas bisa saja pada suatu ketika berbenturan dengan responsivitas. Responsibilitas berhubungan dengan sejauh mana instansi pemerintah melaksanakan segala kegiatannya sesuai dengan prinsip-prinsip dan peraturan yang benar dengan standar professional dan kompetensi teknis yang dimiliki dalam rangka pencapaian tujuan secara optimal. Jadi seperti yang dibahas diatas bahwa responsibilitas dari Puskesmas Rawalele Kabupaten Subang adalah kemampuan Puskesmas Rawalele dalam melaksanakan tugasnya dan tanggung jawabnya untuk memberikan kesehatan kepada masyarakatnya dan menciptakan masyarakat yang mandiri.

Petugas Puskesmas Rawalele Kabupaten Subang juga harus mempunyai kemampuan yang diperlukan untuk memberikan pengarahan kesehatan kepada masyarakat sehingga apa yang dilakukan akan sangat mempengaruhi tercapai atau tidaknya pelayanan yang diberikan kepada masyarakat. Sumber daya manusia atau kemampuan petugas disisi lain juga 
merupakan faktor yang sangat penting dalam suatu organisasi karena mereka merupakan faktor penggerak suatu organisasi, tanpa adanya sumber daya manusia yang handal dan memadai maka mustahil suatu program atau hasil kerja dapat tercapai dengan baik, untuk itu sumber daya manusia yang dimiliki oleh Puskesmas Rawalele Kabupaten Subang dituntut untuk mampu mengembang tugas serta tanggung jawabnya dalam memberikan kesehatan kepada masyarakat dalam upaya menciptakan lingkungan masyarakat yang sehat. Dalam wawancara yang penulis lakukan dengan kepala Puskesmas Rawalele, sebagai berikut: "Sebenarnya program pelayanan gizi balita yang telah pemerintah buat atas kebijakan yang telah ditetapkan ini merupakan suatu tugas pemerintah dan peran petugas dalam menjalankannya dengan baik dan semaksimal mungkin, kami sebagai pemerintah berupaya besar dalam menjalankan program ini sesuai atau tidaknya mungkin masyarakat sendiri yang menilainnya". Adapun dalam wawancara yang penulis lakukan dengan petugas gizi balita, sebagai berikut: "Petugas bekerja sesuai dengan petunjuk teknis yang ada dan melaksanakan sesuai dengan apa yang diharapkan masyarakat, walau masih ada sebagian ibu balita yang acuh akan pentingnya gizi anak balitanya". Berdasarkan hasil wawancara diatas penulis dapat menyimpulkan bahwa upaya yang dilakukan Puskesmas Rawalele adalah agar apa yang diharapkan masyarakat dapat tercapai. Walaupun dalam pelaksanaannya terkadang masih ada masyarakat yang acuh terhadap pelayanan gizi balita. Sedangkan dalam wawancara yang lakukan penulis dengan masyarakat yang mempunyai balita, sebagai berikut: "Pemerintah sudah bekerja semaksimal mungkin walau belum bisa mencapai target dan saya mengharapkan agar pelayanan gizi balita ini bisa ditingkatkan lagi”. Berdasarkan hasil wawancara diatas penulis berkesimpulan bahwa petugas pada saat ini sudah berusaha, berupaya, bekerja dengan keras demi membantu memberikan kesehatan pada balita agar dapat bertumbuh kembang dengan sehat, akan tetapi petugas sedikit kesusahan didalam membangun atau menciptakan suatu komunikasi yang baik dengan masyarakat yang mempunyai balita, karena masih ada sebagian ibu balita yang acuh tidak peduli akan penting tumbuh kembang anaknya tersebut.

Adapun pendapat lain dalam wawancara yang penulis lakukan dengan kepala Puskesmas Rawalele, sebagai berikut: "Petugas berusaha bekerja dengan baik dan menjalankan kewajiban demi memberikan yang terbaik kepada pasien berdasarkan juknis yang ada di Dinas Kesehatan walau masih ada sedikit kendala". Hal ini juga dalam wawancara yang penulis lakukan dengan petugas gizi balita, sebagai berikut: "Walau masih ada sedikit kendala teknis namun sebagai petugas harus bisa bertanggung jawab sesuai dengan juknis yang telah ditentukan, setidaknya sudah berusaha memberikan pelayanan yang bermutu, dengan adanya program pelayanan gizi balita ini setidaknya sebagai petugas sudah membantu tumbuh dan perkembangan anak balita walau belum maksimal".

Berdasarkan hasil kutipan
wawancara diatas penulis menyimpulkan bahwa kinerja puskesmas Rawalele selama ini dalam pelayanan gizi balita telah sesuai dengan juknis yang dikeluarkan oleh Dinas Kesehatan Kabupaten Subang. Namun yang perlu diperhatikan adalah proses pelayanan dilapangan masih ada kendala teknis yang mempengaruhi terhadap Responsibilitas pelayanan. Adapun dalam wawancara yang penulis lakukan dengan masyarakat yang mempunyai balita, sebagai berikut: "Belum sebab masih ada balita yang belum mendapatkan atau tidak kebagian vitamin A juga". Berdasarkan hasil wawancara tersebut dengan masyarakat dapat penulis simpulkan bahwa ungkapan diatas dapat memberi penjelasan bahwa pelayanan gizi balita di Puskesmas Rawalele Kabupaten 
Subang sepenuhnya tekah bekerja sesuai dengan juknis yang ditentukan, namun masih ada keluhan dari masyarakat ibu balita terkait pemberian vitamin $\mathrm{A}$, berdasarkan hal tersebut seharusnya petugas gizi balita dalam memberikan pelayanan gizi balita dapat tercapai dengan baik, sehingga tingkat kesehatan balita dapat lebih jauh baik lagi.

\section{Akuntabilitas}

Dwiyanto

(2006:50-51)

Akuntabilitas publik menunjuk pada seberapa besar kebijakan dan kegiatan organisasi publik tunduk pada para pejabat politik yang dipilih oleh rakyat. Dalam konteks ini, konsep akuntabilitas publik dapat digunakan untuk melihat seberapa besar kebijakan dan kegiatan organisasi publik tersebut konsisten dengan kehendak masyarakat banyak. Akuntabilitas dalam penyelenggaraan pelayanan publik adalah suatu ukuran yang menunjukan seberapa besar kesesuaian peneyelenggaraan pelayanan dengan petunjuk pelaksana yang menjadi dasar atau pedoman penyelenggaraan pelayanan kepada pihak yang memiliki wewenang untuk meminta pertanggung jawaban tersebut. Akuntabilitas pelayanan gizi balita di Puskesmas Rawalele dapat diartikan sebagai bentuk pertanggung jawaban atas penyelenggaraan pelayanan kepada pihak yang memiliki hak dan wewenang untuk meminta pertanggung jawaban tersebut. Pertanggung jawaban Puskesmas Rawalele Kabupaten Subang adalah Kepala Puskesmas Rawalele.

Sebagaimana diketahui bersama bahwa Puskesmas Rawalele Kabupaten Subang tugas pokok melaksanakan penyelenggaraan pemerintahan dan pembinaan kesehatan kepada masyarakat. Dalam kaitanya untuk memberikan kesehatan kepada masyarakat sehingga terciptanya lingkungan yang sehat dan bersih. Akuntabilitas dalam penyelenggaraan pelayanan publik adalah suatu ukuran yang menunjukan seberapa besar kinerja pegawai dalam pelayanan gizi balita, pelayanan dengan petunjuk pelaksanaan yang menjadi dasar atau pedoman penyelenggaraan pelayanan kepada pihak yang memiliki kewenangan untuk meminta pertanggung jawaban tersebut. Dalam wawancara yang penulis lakukan dengan petugas gizi balita, sebagai berikut: "Petugas selalu bertanggung jawab dan bekerja sesuai dengan apa yang diperintahkan oleh pimpinan, hal ini dibuktikan dengan rutinnya dalam membuat laporan kerja ketika kegiatan gizi balita telah dilaksanakan". Berdasarkan hasil wawancara diatas penulis mengambil kesimpulan bahwa petugas Puskesmas Rawalele Kabupaten Subang bekerja sesuai dengan arahan yang diperintahkan oleh Kepala Puskesmas, dengan demikian maka pada dasarnya hasil kerja yang dihasilkan oleh petugas Puskesmas Rawalele Kabupaten Subang akan dapat terpantau langsung oleh Kepala Puskesmas Rawalele. Dengan demikian kinerja dalam pelayanan gizi balita pada Puskesmas Rawalele sudah berjalan dengan prosedur yang diperintahkan langsung oleh Kepala Puskesmas sebagai atasan, keberhasilan program pelayanan gizi balita dapat terealisasikan apabila petugas memang benar-benar bekerja sesuai dengan apa yang diperintahkan oleh Kepala Puskesmas, untuk itu maka pembinaan serta pengawasan Puskesmas Rawalele perlu untuk terus dilakukan agar kinerja dalam pelayanan gizi balita dapat berjalan dengan baik dan hasil yang diharapkan dapat terealisasikan dengan maksimal.

Hal yang sama wawancara yang penulis lakukan kepada Kepala Puskesmas Rawalele, sebagai berikut: "Ketika ada petugas yang tidak bertanggung jawab terhadap perintah yang diberikan, pimpinan akan membahas DPPP (daftar penilaian pelaksanaan pekerjaan), salah satu persyaratan untuk naik pangkat kepada petugasnya". Dari hasil wawancara tersebut penulis dapat menyimpulkan bahwa pertanggung jawaban Kepala Puskesmas Rawalele sudah sesuai dengan prosedur yang ditentukan. Berdasarkan pendapat 
diatas maka penulis mengambil kesimpulan bahwa Kepala Puskesmas Rawalele sudah melakukan sanksi tegas terhadap petugas dalam bekerja dan melayani masyarakatnya, setiap pekerjaan yang tidak sesuai serta melanggar maka akan diberlakukan sanksi mutasi kepada petugasnya, ini berarti seharusnya petugas juga meraasa sadar akan akan hal itu dan bekerja sesuai dengan apa yang seharusnya mereka kerjakan berdasarkan prosedur yang ada. Dalam konteks kinerja dalam pelayanan gizi balita di Puskesmas Rawalele Kabupaten Subang, sanksi yang tegas pada dasarnya akan merangsang lingkungan kerja yang positif sehingga petugas bekerja dengan baik dan sesuai prosedur dalam upaya mencapai tujuan pelayanan gizi balita, akan tetapi pembinaan dan pengawasan perlu untuk terus dilakukan agar arah kebijakan yang telah ditetapkan dapat bertahan.

Berdasarkan uraian tersebut penulis menganalisa bahwa akuntabilitas dalam kinerja pelayanan gizi balita sudah berjalan baik dan ketegasan seorang pimpinan sangat menentukan kinerja petugasnya. Pengaruh kepemimpinan serta kebijkan yang diberlakukan oleh seorang pemimpin berdampak terhadap kinerja yang dihasilkan oleh para petugas sehingga pencapaian tujuan organisasi seharusnya terealisasi dengan maksimal. Pengawasan serta pembinaan petugas juga perlu untuk terus dilakukan agar apa yang telah diberjalan dapat terus ditingkatkan kembali dan akan sangat membantu terhadap pengembangan program dikemudian hari.

\section{Faktor-Faktor Penghambat Kinerja Puskesmas Rawalele Dalam Pelayanan Gizi Balita Di Kabupaten Subang}

Adapun faktor yang menjadi penghambat kinerja Puskesmas Rawalele dalam pelayanan gizi balita di Kabupaten Subang, yaitu :

1. Produktivitas, sosialisasi yang diberikan belum sepenuhnya sampai kepada masyarakat sehingga hasil dari penyuluhan tidak optimal.
2. Kualitas layanan, Setiap ditemukan balita yang bermasalah kurang gizi di 10 desa wilayah kerja Puskesmas Rawalele belum bisa menangani dengan cepat dan tepat dalam memberikan pelayanan hal ini dikarenakan tidak terkapernya akibat jumlah petugas yang terbatas.

3. Responsivitas, lambatnya respon dari pemerintah ketika menerima aspirasi dari masyarakat yang mempunyai balita tentang pelayanan gizi balita, sehingga petugas belum bisa merealisasikan sepenuhnya aspirasi dari masyarakat yang mempunyai balita tersebut.

4. Responsibilitas, adanya ketidaksesuaian dalam hal pemberian vitamin A Dan PMT kepada masyarakat yang mendapatkan pelayanan gizi balita.

\section{SIMPULAN}

Kinerja Puskesmas Rawalele dalam pelayanan gizi balita di Kabupaten Subang diukur menggunakan lima indikator yaitu Produktivitas, Kualitas layanan, Responsivitas, Responsibilitas, Akuntabilitas. Berdasarkan hasil pembahasan yang telah diuraikan mengenai kinerja petugas Puskesmas Rawalele dalam pelayanan gizi balita menunjukan bahwa ada empat indikator yang belum bisa terbina dan terselesaikan dengan baik, Produktivitas, Kualitas layanan, Responsivitas, dan Responsibilitas. Hanya ada satu indikator yang sudah terbina dengan baik yaitu Akuntabilitas.

\section{DAFTAR PUSTAKA}

1. Dwiyanto, Agus. 2006. Reformasi birokrasi publik di Indonesia.

Pusat Studi Kependudukan dan Kebijakan, Universitas Gadjah Mada. Yogyakarta

2. Mooney. 1996. Manajemen Pelayanan Umum di Indonesia. PT. Bumi Aksara: Jakarta 
3. Soerjadi. 2009. Pengembangan Kinerja Pelayanan Publik. Bandung.

4. Tangkilisan, Hessel Nogi S. 2005. Manajemen Publik. Jakarta: Gramedia Widiasarana Indonesia

5. Ratminto \& Septi, Atik Winarsih. 2005. Manajemen Pelayanan. Cetakan IX. Pustaka Pelajar: Yogyakarta

6. Mahmudi. 2010. Manajemen Kinerja Sektor Publik. Cetakan Pertama. Yogyakarta: Unit Penerbit dan Percetakan

7. Moenir. 2002. Manajemen Pelayanan Publik. Bina Aksara: Jakarta
8. Creswell, John W. 2010. Research Design: Pendekatan Kualitatif, Kuantitatif, dan Mixed. Yogyakarta: Pustaka Pelajar

9. Nazir. 2003. Metodologi Penelitian Sosial: Teori-Aplikasi. Bumi Aksara

\section{Dokumen}

Undang-Undang Nomor 25 tahun 2009 tentang pelayanan publik

Keputusan Menteri Pemberdayaan Aparatur Negara Nomor 63 tahun 2003 tentang pedoman umum penyelenggaraan pelayanan publik 